\title{
AN ANALYSIS OF STUDENTS' ERRORS IN WRITING COMPARATIVE AND SUPERLATIVE ADJECTIVE
}

\author{
Natalia Widya Pasca Tarigan
}

Universitas Prima Indonesia

Corresponding Author: nataliatarigan@unprimdn.ac.id

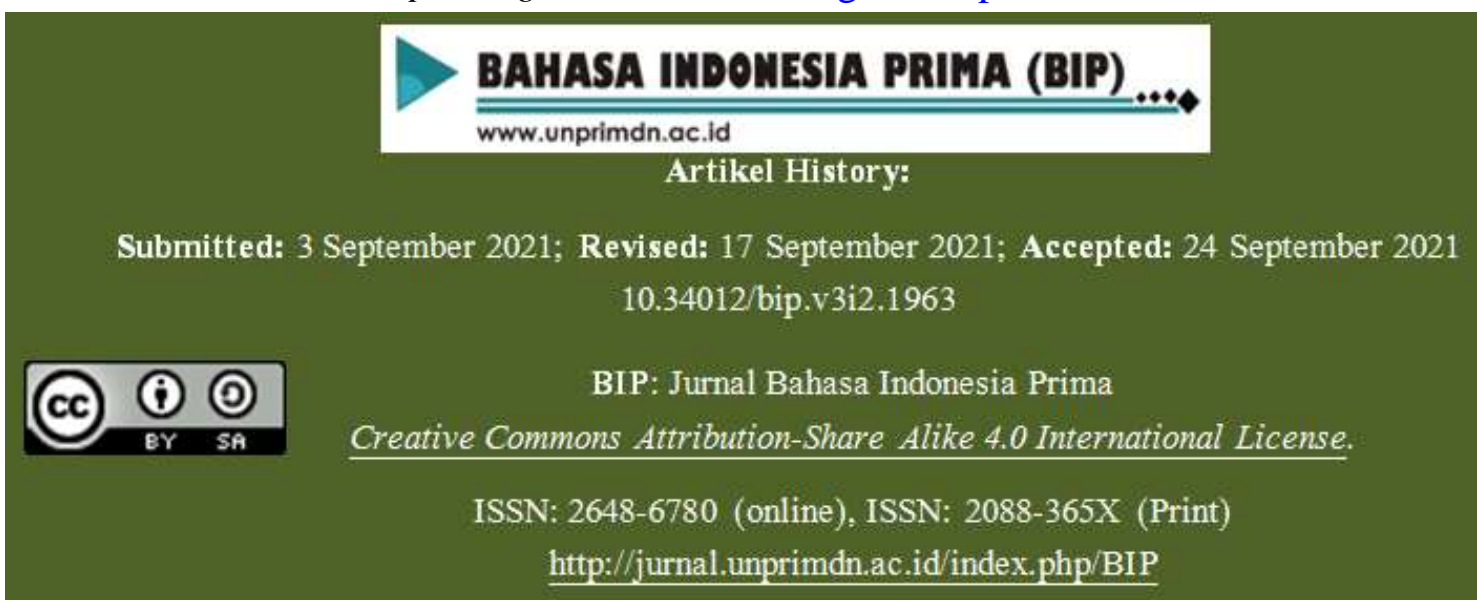

Abstract-This research was conducted to find out the impact of writing comparative and superlative adjective to analyze students' errors in writing and toobserve the students' error in writing. The main purpose of the research is to observe if students get the errors in their writing comparative and superlative adjective. Qualitative research is used. The findings indicated that the error of misinformation $43.28 \%$, error of misordering $22,11 \%$, error of addition $18,07 \%$, and error of omission $16,52 \%$. It showed that students encounter problems and difficulties in writing comparative and superlative adjective. The conclusion is that educators should provide more effective ways in teaching comparative and superlative adjective so that the students can be better in using that in writing.

Keywords : Student's error, Writing Skill, Comparative and Superlative Adjective

\section{A. Introduction}

In globalization era, English is very important of International communication due to English is one of the International of the world. The importance of English in this era cannot be denied. Many aspects of our lives cannot be separated from the influence of English because it has many roles in technology, socio-cultural, economy, art, science, education and so forth. Mastering English is necessary and becomes a challenge for humanity. The general purpose of English study is to develop communicative competence in English both oral and written. Communicative competence involves the mastery of English language skills such as writing, listening, reading and speaking.

Students often encounter difficulties and make errors in using comparative and superlative adjectives especially to determine which adjective should be added by $-e r+$ than or more + adjective + than in comparative degree and the + -est or the + most + adjectivein superlative degree. Moreover, students are getting confused with the particular syllables in using comparative, superlative adjectives in writing.

Moreover, in this research students willbe observed by the researcher in using 
comparative, superlative adjectives in writing and the errors the students will make, for example the way students add er for comparative and -est for superlative adjectives. Students will be interviewed by the researcher regarding the difficulties and errors in comparative and superlative degree. 1). The Problems of the study are What are students' errors in using comparative and superlative adjectives in writing? 2). How do students use compartive and superlative adjectives in writing? 3). Why do students make errors in using comparative and superlative adjectives in writing? The objectives of the study are 1). To find out the kinds of errors which are made in using comparative, superlative adjectives 2).

To find the difference between the use of comparative and superlative adjectives especially in using -er or -est and differentiate the syllables which is added by -er or -est in SMA Free Methodist-1. $3)$. To find the reason why students make errors in usig comparative and superlative adjectives. The scope of the study was to determine the errors that students make using comparative, superlative in writing and the researcher will observe 15 students. Also, researcher will provide 20 questions for each student. The significances of the study were to improve the students' competence in using comparative, superlative adjectives and the difference in using every formula for comparative and superlative adjectives; The finding of this study may be helpful for the English teacher to be employed in his or her teaching practice. It can be one of choices to do in the classroom; The finding of this study will be helpful for the other researchers because by getting the clear infomation and methods in using comparative and superlative adjectives in
English, students' errors can be avoided or solved using the proper structure from comparative and superlative degree.

We know that in English, there is a term that called as parts of speech and adjective is included in part of speech also there are some kinds of adjective. Accroding to Thomson (1986:33) the main kinds are: 1). Demonstrative, such as: this, that, these, those; 2). Distributive, such as: each, every, either, neither; 3). Quantitative, such as: some, any, no, little, few, many, much; 4). Interrogative, such as: which, what, whose; 5). Possessive, such as: my, your, his, her, its, our, your, their; 6). Quality, such as: clever, dry, fat, golden, good, heavy, square.

According to Alexander (1994:80) adjectives can be formed from verbs or nouns added with suffixes and prefixes. According to Thomson (1986:33), the position of adjectives can be attributive and/or predicative. Attributive adjectives are adjectives that come before nouns, for example: this book, that boy, which table, our house, meanwhile predicative adjectives are adjectives that come after verbs, for example: be, seem, become, such as: Agnes becomes rich and her family seems happy. Another example is the adjectives that come after verbs such as: appear, feel, get, grow, keep, look, make, smell, sound taste, turn, for example Tom felt cold, She made him sad, the solution sounds great.

Some adjectives can be used only attributively or predicatively and some change their meaning when moved from one position to the other, for example: $A$ small farmer means that a man who has small a small farm. The farmer is small means that he is a small man physically.

Comparative degree indicates that something has more quality than 
something else. The pattern of comparative degree are: 1). Adjective + er + than. (Example: bigger, smaller, taller, shorter than). 2). More + adjective + than (Example: more beautiful, more handsome than). The writer also gave examples in sentences: 1). My bag is bigger than yours. 2). My sister is taller than me. 3) The girl with blue skirt is more beautiful than the girl with red skirt.

There are some forms of irregular comparison in comparative degree. It can be explained through table below. Superlative degree indicates that something has more quality than anything of its kind. The pattern of Superlative Degree is: 1). The + adjectives + est (Example: the smallest, the biggest, the tallest). 2). The + most + adjective (Example: the most beautiful, the most expensive). There are also Examples in sentence: 1). She is the most beautiful girl in her campus. 2). Toni is the smartest student in his class. 3 ). This handphone is the most expensive one that I have ever bought.

The rules of Superlative Degree can be described throgh the table below. There are some forms of irregular comparison in comparative degree: Best Worst Most Latest, late Nearest especially when making an official decision. Meanwhile, based on Collin Dictionary, p. 119, error is a mistake or something that you have done wrong. According to Chomsky as stated by Dulay (1982:139), there are two types of error. The first is error caused by fatigue inattention (performance) and the second is error that resulting from lack of knowledge of the rules of the language.

According to Dictionary of Linguistics and Phonetics (Crystal, 1991:112), error analysis is a technique for identifying, classifying and systematically interpreting the unacceptable forms produced by someone learning a foreign language. The unacceptable forms refer to the error made by the learner. It is unacceptable since it does not correspond to the foreign language norm being learnt. Brown also proposes the same definition that erros can be observed, analyzed and classified o reveal something of the system operating within the learner, led to rush forward of the study of learner's errors (Brown. 1994:206).

Additionally, theoretical interest in a study of errors gives feedback to both descriptive linguistics and psycholinguistics (Corder, 1973:266). In descriptive linguistics, error analysis involves the explanation of errors in terms of the linguistic process or rules that are followed by students. At this point, the students' errors are examined in terms of syntactic and semantic linguistics. On the other Farthest (distance), Futherless, in psycholinguistics, error analysis (distance and additionalprovides and explanation on how errors may occur in language production. Studying learner's errors is useful for the researcher, teachers and the learners themselves Fewest (countable noun) investigate.

There are some definition of errors. Based on Oxford Dictionary, p.529, error is 1) a mistake when you are working on a computer, which means that the computer program cannot do what you want it to do, 2) a mistake in the way that you examine a situation and decide what to do, 3) to have made a mistake, from which inferences about the nature of the language learning process can be made. Second, it helps teachers and curriculum developers to provide the data on which part of the target language that the students have most difficulty and which error type detract most from the learner's ability to 
communicate effectively. From the statement above, it means that errors analysis is very important especially for the teachers. Errors can be used as the feedback because by knowing the learners' errors, the teachers can realize whether their material and their technique are effective or not. Moreover, error analysis has the purpose to investigate which difficult parts that the learner or students face.

This study describes some works which are relevant to the thesis in order to make the thesis arrangement easier: 1). Review entitled "Adjective Comparison in Contemporary British English" by Engelska and C-Uppsats, it is stated that there are two wasy of comparing adjectives in English, such as the analytic and the synthetic, the analytic way is to use more and most meanwhile the synthetic way is to add the endings -er and - est. The finding of this review is that students have difficulties in differentiating the syllables in comparative and superlative adjectives. 2). Review entitled "Defining Writing Ability for Classroom Writing Assessment in High Schools" by Jji- Yeon Yi, it is stated that since writing ability is multifaceted in its own right, any approach and accordingly its definition of writing ability cannot be thorough and comprehensive in its own right. The finding of the research is that writing is able to be one of the approach in classroom activity.

\section{B. Research Method}

This research design was very suitable for this study since it fulfills the characteristics of qualitative research. There are four characteristics of a qualitative research, such as: First, natural setting, it means that in qualitative approach, the intent is to explore human behavior within the context of their natural occurence. Second, researcher as data gathering instrument, these data include field notes from participants observations, notes from transcriptions of interview with informants, andunobtrusive data such as artifact from the research site or record related to the social phenomena inder investigation. Third, inductivedata analysis, it means that qualitative researcher do not begin with null hypothesis to retain. Fourth, reflectivity, it is understood that the act of studying a social phenomenon influences the enactment of that phenomenon. This research was conducted at SMA Free Methodist 1 which is located at Jalan Beringin Raya No 152E, Helvetia, Medan Helvetia, Kota Medan, Sumatera Utara 20123 and the time will be in June 2019. Subject of the research is the group of students or individual who will be involved in the research which will be conducted by the particular researcher, meanwhile object of the research was the goalor purpose that was obtained from the research. In this particular research, students from SMA Free Methodist 1 was the absolute subject of the research and the object of the study was to find errors which were made by students in using comparative and superlative adjectives in writing. The researcher provided 20 questions for each student in writing form doing comparative and superlative adjectives.

In order for the researcher to obtain the required data, the researcher used some techniques in this research such as observation, interview, instrument and documentation. Research instrument were the measurement tools (questionnaires or scales) designed to obtain data on a topic of interest from research subjects. 
Research instrument could be classified into two different types, such as: Research Instrument Records, Research Instrument Validation and Utilization Records, Research Instrument. For this particular research, the researcher will use writing as the instrument which the researcher will provide some exercises in comparative and superlative adjectives. Students will be given time to do the exercises and when they are done, the researcher will check the errors that has been made by the students and guide them how to correct the erros.

Based on "The Ultimate Guide to Writing a Dissertation" by John Dudavskly in every qualitative research, the researcher should obtain qualitative data which is non-numerical data in order to draw a particular conclusion. Qualitative data refers to non-numerical information such as interview transcripts, notes, video and audio recording, images and text documents. Qualitative data analysis can be divided into the following five categories, such as: Content analysis, Narrative analysis, Discourse analysis, Framework analysis, and Grounded theory.

According to Dye, J.G. Schatz, I.M., Rosenberg, B.A., and Coleman, S.T. (2000, January), Constant comparison method: A kaleidoscope of data, The Qualitative Report, 4(1/2), just as a quantitative study cannot be valid unless it is reliable, a qualitative study cannot be transferable unless it is credible and it cannot be credible unles it is dependable. In this research, the researcher will prove the wortiness by persistent observations and providing written exercises in comparative and superlative adjectives. The researcher will check the errors that will be made by the students and provide the result of the exercises to prove that students make some errors and there is correctionprovided by the researcher.

\section{Results and Discussion}

Table: The percentages of students' error ineach type

\begin{tabular}{|c|c|c|c|}
\hline & $\begin{array}{l}\text { Types of } \\
\text { Error }\end{array}$ & $\begin{array}{l}\text { Frequency } \\
\text { of Error }\end{array}$ & $\begin{array}{l}\text { Percentag } \\
\text { e of Error }\end{array}$ \\
\hline 1 & Mis formation & 364 & $\begin{array}{l}364 \\
84 \\
1 \quad x \quad 100 \% \\
= \\
43,28 \%\end{array}$ \\
\hline 2 & Misordering & 186 & $\begin{array}{l}186 \\
84 \\
1 \times 100 \%= \\
22,11 \%\end{array}$ \\
\hline 3 & Addition & 152 & $\begin{array}{l}152 \\
84 \\
1 \quad x \quad 100 \% \\
= \\
18,07 \%\end{array}$ \\
\hline 4 & Ommission & 139 & $\begin{array}{l}139 \\
84 \\
1 \times 100 \% \\
16.52 \%\end{array}$ \\
\hline & Total & 841 & $100 \%$ \\
\hline
\end{tabular}

\section{CONCLUSIONS}

After analyzing the data from the student errors in writing comparative and superlative adjective the conclusion can draw as the types of commited by eight grade students of SMA Global Prima Medan are error of misinformation $43.28 \%$, error ofmisordering $22,11 \%$, error of addition $18,07 \%$, and error of omission $16,52 \%$. So the dominat error of misinformation that $43,28 \%$.

The reasons based on the interview why the students made errors in using 
BIP: Jurnal Bahasa Indonesia Prima Vol. 3, No. 2, 2021, September 2021, PP.

degrees of comparison are students do not understand in one or more syllable incomparative and superlative with the reasons are less of reading grammar and low motivation.

Based on the conclusion above, it canbe delivered some suggestions:

1. English teachers are suggested to teach how to use comparative and superlative adjective in sentence, both oral and written clearly and completely.

2. English teachers should give more exercises and practices to the students regarding any kinds of examples of comparative and superlative adjective.

3. Students should learn more diligently.

4. Students should read any kinds of grammar books to enrich their ability in understanding language structures.

5. School should provide some books whichhelp students.

\section{REFERENCES}

Alexander, L G. 1994. Longman English Grammar Practice for Immediate students. London : Longman Group Ltd.

Brown, H.D. 1994. Principles of language Learning and Teaching. New Jersey : Prentice hall Inc.

Corder, S.p. 1973. Introducing Applied linguistics. New York ; Penguins book Ltd.

Crystal, D. 1991. A Dictionary of Linguistic and Phonetics.Oxford: Blackberry.

Dulay, Heidis, et all 1982. Language
two.New York : Oxford University Press.

Fye, J.G, Schatz, I.M. Rosenberg, B.A and Coleman, S.T. (2000, Jnauary), Constant comparison Method : A Kaleidoscope of Data, The Qualitative Report, 4(1/2).

Thomson, A J and Martinet, A V. 1986. A Practical English grammar, London : Longman Group Ltd. 